October 6, 2013

Address correspondence to:

ramseyer@law.harvard.edu

erasmuse@indiana.org

Goal: 5000-7500 words

Currently: 6,465 words (including everything)

\title{
Exclusive Dealing: Before Bork, and Beyond
}

\author{
J . Mark Ramseyer and Eric B. Rasmusen*
}

\begin{abstract}
:
Antitrust scholars have come to accept the basic ideas about exclusive dealing that Bork articulated in The Antitrust Paradox. Indeed, they have even extended his list of reasons why exclusive dealing can promote economic efficiency. Yet they have also taken up his challenge to explain how exclusive dealing could possibly cause harm, and have modelled a variety of special cases where it does. Some (albeit not all) of these are sufficiently plausible to be useful to prosecutors and judges.
\end{abstract}

*J. Mark Ramseyer, Mitsubishi Professor, Harvard Law School, Cambridge, Massachusetts 02138, 617-496-4878; Eric B. Rasmusen, Dan R. and Catherine M. Dalton Professor, Kelley School of Business, Indiana University, Bloomington, Indiana 47405-1701, erasmuse@indiana.edu, 812-855-9219.

http:// papers.ssrn.com/sol3/papers.cfm?abstract_id=2308218

We would like to thank John Shepherd Wiley Jr. and participants in the Yale Bork conference and Indiana's Kelley School of Business's BEPP Brown Bag Lunch for useful comments. 


\section{Introduction}

In an "exclusive-dealing" contract, one party agrees to trade only with the other, typically a retailer buying from a supplier. Courts have never banned such contracts outright, but in the years before The Antitrust Paradox they came close.

Robert Bork helped reverse the law's course. As profoundly as any book ever changes the law, his 1978 The Antitrust Paradox changed the way judges handled exclusive-dealing contracts. ${ }^{1}$ Before Bork, they routinely held the deals illegal. After Bork, they routinely approved them unless one of the parties could explain why the contract cut consumer welfare. ${ }^{2}$ More specifically, they approved them unless a plaintiff could show that the exclusive agreement did not just hurt rival suppliers, but also plausibly reduced competition. To make that showing, the plaintiff needed to prove that the defendant had market power, and that the contract at least sustained that power. At trial, a defendant could defend by showing the contract's fundamental efficiency.

In demonstrating the mutually beneficial character of exclusive-dealing contracts, Bork ended an approach that courts had begun mid-century. Early in the 20th century, courts applying antitrust law had focused on price conspiracies and let most firms negotiate exclusive dealing contracts as they pleased. A few decades later, they began to think the contracts could restrict competition, and help dominant firms acquire market power and monopolize the market. Rather than let dominant firms do that, they began to hold the contracts illegal.

Bork stopped that mid-century shift with a critique that followed two developments in economics. First, basic price theory, straightforward prose with some diagrams and simple equations on the side, cleanly showed that the usual idea of how exclusive-dealing contracts hurt competition didn't make sense. Second, closer examination of the specific industries involved in the cases often disclosed substantial benefits from exclusive contracts for retailers as well as suppliers. ${ }^{3}$

Post-Bork, scholars have tried to explore when exclusive dealing contracts might still cut efficiency, notwithstanding his basic price theory. Much of this work has involved game theory and complex mathematical techniques. For the

${ }^{1}$ Unless otherwise noted, all page references to Bork will be to The Antitrust Paradox.

2 Courts at common law usually did not object to exclusive contracts. See Jacobson (2002); Mitchel v. Reynolds, 24 Eng. Rep. 347 (Q.B. 1711); Catt v. Tourle, L.R., 4 Ch. App. 654 (1869); Mogul Steamship v. McGregor, Gow, All E.R. Rep. 263 (1891); Chicago, St. Louis \& New Orleans R.R. v. Pullman Southern Car, 139 U.S. 79 (1891). An exception is Davenant v. Hurdis (The Mrrchant Taylors Case), 72 Eng. Rep. 769 (K.B., 1599), which Letwin (1953) considers the first monopoly case in England. The case refused to enforce a guild's exclusive-dealing rule as allowing one company to monopolize a trade. Cases in the United States are brought under Sec. 1 (conspiracy) or Sec. 2 (monopolization) of the Sherman Act, Sec. 3 of the Clayton Act, or the FTC Act. They can be filed the Department of J ustice, the Federal Trade Commission, or private plaintiffs. See the ABA's 2006 “Resources for Exclusive Dealing Agreements" for a compendium of links to both law and economics.

3 More than anyone else, Benjamin Klein brought a flair to locating these reasons, but others have sometimes folded the approach within "transaction cost economics" or "the new institutional economics." 
most part, it flies under the heading "Post-Chicago". Given that all of it builds on basic price theory, one could just as accurately call it the "Neo-Chicago" or simply "modern antitrust theory."

We stress at the outset that this is not a literature review. We have not tried to survey most articles, or even the most important articles. Instead, we explore some of the impact that The Antitrust Paradox has had. Precisely because of the strength of Bork's work, that impact has been huge. And one measure of its enormity lies in the volume of excellent scholarship that it engendered. We urge readers to understand that we do not purport to catalog that scholarship here.

\section{Bork and Exclusion}

It is a melancholy tale Bork tells. Its low point comes in 1949. J ustice Frankfurter told Standard Oil of California that it could not sell gasoline to service stations using exclusive dealing contracts:

'...Admit also that control of distribution results in lessening of costs and that its abandonment might increase costs. ...Concede further, that the arrangement was entered into in good faith, with the honest belief that control of distribution and consequent concentration of representation were economically beneficial to the industry and to the public... Nevertheless, as I read the latest cases of the Supreme Court, I am compelled to find the practices here involved to be violative of both statutes. For they affect injuriously a sizeable part of interstate commerce...

[The] observance by a dealer of his requirements contract with Standard does effectively foreclose whatever opportunity there might be for competing suppliers to attract his patronage .... Standard's use of the contracts creates just such a potential clog on competition as it was the purpose of $\S 3$ to remove .... CITE

Standard Oil Co. of Calif. v. U.S., 337 U.S. 293, 299, 314 (1949)(Frankurter, J .) It could have been worse. J ustice Douglas dissented-but he saw exclusionary contracts as weapons of populist Robin Hood stations in the war against King Standard Oil:

Big business has become bigger and bigger. Monopoly has flourished. Cartels have increased their hold on the nation. The trusts wax strong. There is less and less place for the independent. The full force of the Anti-Trust Laws has not been felt on our economy. It has been deflected. Niggardly interpretations have robbed those laws of much of their efficacy. ... The elimination of these requirements contracts sets the stage for Standard and the other oil companies to build service-station empires of their own.

Standard Oil Co. of Calif. v. U.S., 337 U.S. 293, 315-316, 320 (1949)(Douglas, J ., dissenting).

Frankfurter and Douglas both missed the crucial question of whether exclusive-dealing contracts could both help the excluder and harm the public. Suppose each of 90 retailers has Figure 1's demand curve, and each of 9 upstream 
suppliers has a constant marginal cost of $\$ 10$. The result is a wholesale price of $\$ 10$. If each retailer buys 30 units, each will earn surplus of $\$ 450$. Suppose further that each supplier sells to 10 retailers (300 units per supplier).

\section{Figure 1 One Retailer's Demand Curve}

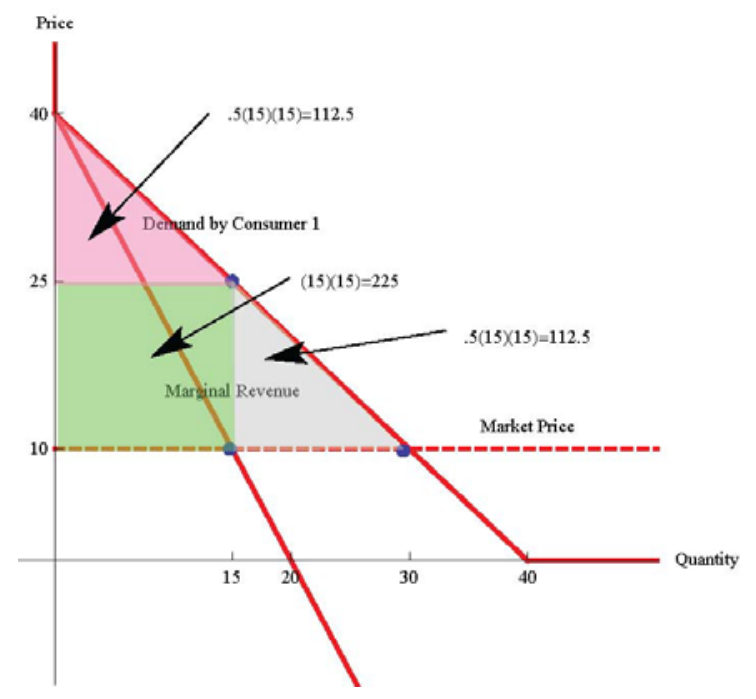

Now posit that Supplier 1 asks the retailers to sign exclusive-dealing contracts with him, so he can lock up the market. Will his evil plan work? No. Rational retailers will refuse to sign on. They have a choice between Suppliers 2-9, who sell without exclusive-dealing clauses, and Supplier 1, who demands exclusivity. They will see no reason to become captive customers of Supplier 1.

To induce retailers to sign, Supplier 1 must add a signing bonus. A retailer will foresee that if he signs on, Supplier 1 will raise the price to $\$ 25$, imposing two costs on the retailer. First, the retailer will not want to buy as much at the higher price, and by cutting his purchases from 30 to 15 in Figure 1 he will lose gains from trade of $\$ 112.50$. Second, he will have to pay $\$ 25$ instead of $\$ 10$, costing him a total of $\$ 225$. Thus, the retailer will require a signing bonus of $\$ 337.50$. This, however, ruins the scheme's profitability, because Supplier 1 will only earn monopoly profits of $\$ 225$ from this retailer. The logic resembles predatory pricing: it's easy to monopolize if you're willing never to earn any profits. Maybe Douglas's power-hungry monster would do that, but not a greedy corporation. For Bork, per se legality followed straightforwardly. But he saw that exclusive-dealing contracts were not only harmless; they could increase the gains from trade between supplier and retailer, as we will next see.

\section{Efficiency Reasons for Exclusion Contracts}

Even before The Antitrust Paradox, judges understood many of the reasons why exclusive-dealing contracts might be efficient. Frankfurter mentions several in Standard Stations. Skeptical lawyers can start by looking at their own profession. As Meese (2005) notes, a partner at Skadden Arps cannot 
"moonlight" for Cravath, Swaine \& Moore, and when Apple and Samsung sue each other over patents, partners at Cravath cannot work for both sides. There are a number of reasons why exclusive contracts might be efficient.

(1) Free-riding. An exclusive-dealing contract can prevent a retailer from using one supplier's marketing efforts to attract customers and sell them a rival supplier's goods (Marvel [1982], Segal and Whinston [2000b], Klein (2003)). That is perhaps what is going on in the 1948 Griffith case, except to protect the "retailer": certain movie theatres bargained and got exclusive rights to the first run of a movie in their towns (United States v. Griffith et al. 334 U.S. 100 (1948)). Similarly, an exclusive dealing contract can prevent a retailer from using one supplier's reputation for quality to persuade the customer of a product's value and then selling him a cheap copy (the obvious danger with dress patterns in Standard Fashion v. Magrane-Houston, 258 U.S. 346 (1922) and Fashion Originators' Guild of America v. FTC, 312 U.S. 457 (1941), both discussed in Bork [1978] p. xxx).

(2) Hold-up. Sometimes a supplier can serve a retailer effectively only if he first makes a series of retailer-specific investments. Once he invests, though, he leaves himself vulnerable to hold-up by the retailer, who can try to renegotiate the contract to a lower price. An exclusive contract mitigates that risk by making the retailer vulnerable to the supplier as well. See Tampa Electric v. Nashville Coal, 365 U.S. 320 (1961) and its description in Klein (2003). Suppose a retailer gets a benefit of 16 from a product, and suppliers have a cost of 12, but could spend 4 and reduce their cost to 6 , and prices cannot be precontracted. Without exclusivity, after a supplier reduced his cost, the retailer would bargain him down to a price of 9 , halfway between 6 and 12, if they have equal bargaining power, and the supplier would end up with a loss. With exclusivity, the price would be 11, splitting the difference between 6 and 16, and the supplier would have a profit and be willing to make the investment.

(3) Planning. Often, both the supplier and the retailer need to plan production and marketing. All else equal, the supplier would prefer a fixed-price fixed-quantity contract, and the retailer would prefer a fixed-price requirements contract. A fixed-quantity contract would force the retailer to accumulate inventory if consumer demand fell; a requirements contract would shift that inventory problem to the supplier. Given this tension, an exclusive dealing contract constitutes something of a compromise: the retailer does not promise to buy a given quantity, but he does at least promise not to switch acquisitions to a rival supplier. As a result, the contract protects the supplier against the risk of losing market share to a rival supplier, at the same time that it protects the retailer against swings in consumer demand. Bernheim and Whinston (1998) have modelled this, in a setting where two risk-neutral suppliers compete for the business of one risk-averse retailer. With exclusive dealing required, Supplier 1 can pay a big signing bonus to the retailer, but then also bind it to a high per-unit 
price, which gives the retailer safe profits if consumer demand is weak but lower profits if it is strong. Without exclusive dealing, however, the retailer would accept the bonus and then buy from Supplier 2 instead, at a lower price. ${ }^{4}$

(4) Allocation of Limited Resources. Sometimes what looks like an exclusive contract is just a simple sale. In particular, it is a sale of a good that, like any private good, is rivalrous. Take shelf space. Suppliers bid for the right to place their goods on a particular place on a retailer's shelf. There is only limited room on the eye-level shelf; some supplier's product is going to end up where shoppers have to stoop to see it. It would be absurd to insist that retailers not promise by contract that a particular supplier who pays more will get the best shelf; the price mechanism is needed to get the most efficient allocation. ${ }^{5}$

If oligopolists compete for the entire business of a retailer instead of just for a particular order, the nature of the strategic interaction changes. They could compete at a supermarket for sales on a daily basis, or they could compete once a year for exclusive shelf space. Which arrangement benefits consumers most remains inconclusive, as the debates among Lin (1990), O'Brien and Shaffer (1993), Farrell (2005), and Klein and Murphy (2008) illustrate.

(5) Confidentiality. A retailer handling a product stands in a good position to learn its supplier's trade secrets, marketing plans, and other intellectual property. If he handles competitors' products too, he has easy opportunities accidentally to disclose or intentionally to sell those secrets. See Joyce Beverages v. Royal Crown Cola, 555 F. Supp. 271, 276 (S.D.N.Y. 1983) and R.W. Int'l. v. Welch Foods, 13 F.3d 478 (1st Cir. 1994).

(6) Quality Assurance. A high-quality supplier may fear a retailer will sell a competitor's low-quality product and sell it as the high-quality brand. That is harder if the retailer is not allowed to buy even an ounce of the competitor's product. See Sinclair CITE, 261 U.S. at 475-476.

(7) Increased Efficiency of Existing Market Power. Through exclusive-dealing contracts, a monopolist supplier can create a downstream horizontal monopoly and avoid the risk of double marginalization. This is useful if the retailers have market power and resale price maintenance can be used. Given that double marginalization hurts both suppliers and consumers, this possibility does not justify antitrust intervention.

4 Note that although exclusive-dealing is motivated by efficiency here, it does result in a higher price for the consumers, because the monopoly retailer is purposely accepting double marginalization in return for reduced risk.

5 Wright (2006), Klein and Wright (2007), Bronsteen et al. (2005); R.J. Reynolds Tobacco v. Philip Morris, 199 F. Supp. 2d 362 (M.D.N.C. 2002). This is the point Coase (1979) made in the context of radio payola: disc jockies deciding which songs to play based on the payments from the record companies. 
(8) Attaining Economies of Scale. Bernheim and Whinston (1998) point out that if suppliers can reduce their unit cost by a fixed investment, then a retailer in their first market can agree to deal exclusively with one supplier so that it finds it more worthwhile to make the investment in reducing marginal cost and seize a different, "noncoincident market". It seems the argument would extend to technologies with a learning curve and many retailers. Whether exclusion ends up reducing welfare or increasing it is complex.

\section{Bad Motives for Exclusion Contracts.}

Seeing no rational bad motives for exclusive-dealing contracts but more than one good motive, Bork proposed a safe harbor: make the contracts legal per se. "The truth appears to be," he explained (p. 309), "that there has never been a case in which exclusive dealing or requirements contracts were shown to injure competition."

Perhaps Bork lost his way in his own rhetoric. Later (pp. 344-345), he gave his own example of an exclusive contract he thought the court rightly banned: Lorain J ournal v. U.S., 342 U.S. 143 (1951). The Journal, a local newspaper, required its advertisers not to advertise with the local radio station. To Bork, the regulation of the radio spectrum gave the station a monopoly that the Journal, if it could but acquire the station, could profitably exploit. Explained Bork (p. 345):

The radio license, which the Journal had earlier unsuccessfully applied for, constituted a monopoly protected by the government. If the Journal could bankrupt [the station] and gain the license, it would ... have much better reason than most predators to hope to be secure from further entry into its market.

(1) Naked Exclusion/ Divide-and-Conquer. Since The Antitrust Paradox, economists have worked hard to find potentially bad motives for these contracts. We ourselves (Rasmusen, Ramseyer and Wiley [1989]) suggested one: sometimes everyone involved expects that a supplier can lock up enough of a market through exclusive dealing contracts that no rival will achieve the minimum efficient scale of operation. 6

${ }^{6}$ Areeda, as quoted by Bork (p. 304), foreshadows this idea by worrying that exclusion could "deprive rivals of the business that would otherwise permit them to operate at an efficient scale..." Similarly, Kaplow (1985: 532) notes: "If ... many customers are buying the product of an industry that is becoming more concentrated, each buyer will be unwilling to incur a significant expense in preventing the concentration because it bears the total cost of any of its efforts but ony receives a benefit in proportion to its share of the market. Each buyer reasons that it can take a 'free ride' on the efforts of the other buyers who will bear the expense of preventing the rise of concentration." 
Return to Figure 1's example, but with different cost curves. Now, let each supplier have annual fixed costs of $\$ 400$ and a marginal cost of $\$ 8$ up to output of 200 units and $\$ 10$ beyond, as shown in Figure 2.7

Figure 2

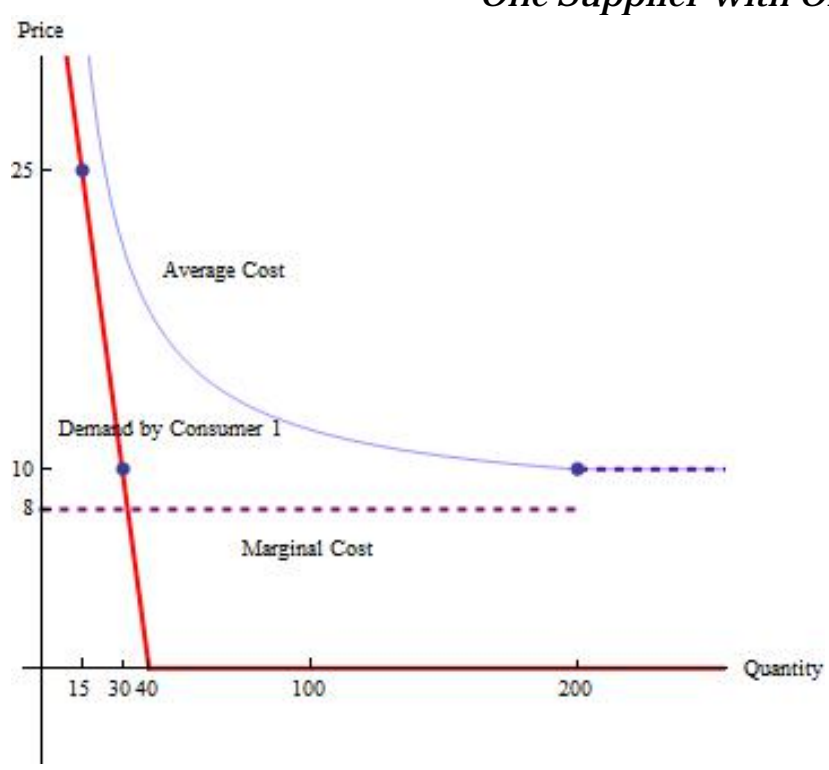

One Supplier with One Customer

The competitive equilibrium will be a market price of $\$ 10$, with each retailer buying 30 units and earning retailer surplus of $\$ 450$. Each supplier would sell to 10 retailers at a price of $\$ 10$, for a quantity of 300 per supplier and marginal cost of $\$ 8$ for the first 200 units, so it would earn quasi-rents of $\$ 400$, just what it needs to pay for its fixed cost. Given these cost curves, for each supplier 200 units represents the minimum efficient scale of production: at a price of $\$ 10$, unless it can sell 200 units it cannot recover its $\$ 400$ fixed cost. Any supplier who anticipates selling less than 200 units would exit the market.

Suppose Supplier 1 now offers retailers an exclusive-dealing contract with a signing bonus of $\$ 1$. What happens next depends on expectations. If Retailer 1 thinks nobody else will sign the contract, he will not sign it either, just as in our first example, since $\$ 1$ is far too low to compensate for having to pay a price of $\$ 25$ instead of $\$ 10$. Suppose, however, that Retailer 1 thinks the other 89 retailers will all sign on with Supplier 1 . If Retailer 1 signs too, he will get the signing bonus of $\$ 1$ and will have to pay a price of $\$ 25$, a bad outcome. But his alternative is worse. If he refuses to sign, he would be the only retailer left in the market for the other 8 suppliers. Each supplier, though, needs to sell enough units to cover a fixed cost of $\$ 400$. At a price of $\$ 10$ for 30 units and a marginal cost of $\$ 8$, Supplier 2's payoff would be 30 $\$ 10$ - $\$ 8$ ) - $\$ 400=-\$ 340$. Anticipating this, Supplier 2 (and Suppliers 3 through 9) would exit the market. Given this logic, Retailer 1 has a choice: (a) not buy at all, for a payoff of $\$ 0$, or (b) return

7 Average cost for $\mathrm{Q}<200$ is $(8 \mathrm{Q}+400) / \mathrm{Q}=8+400 / \mathrm{Q}$, which equals 10 at $\mathrm{Q}=200$. Average cost for $\mathrm{Q}>200$ is $[8 * 200+400+10(\mathrm{Q}-200)] / \mathrm{Q}=[2000+10 \mathrm{Q}-2000] / \mathrm{Q}$, which equals 10 . 
humbly to Supplier 1 and pay $\$ 25$ without any signing bonus, for a payoff of $\$ 112.50$. Humiliation wins.

As this example makes clear, "naked exclusion" works only if Supplier 1 can foreclose a large enough fraction of the market to deny competitors the minimum efficient scale. If sufficient suppliers remain to serve those retailers who refuse the contract, "naked exclusion" fails. Thus, this strategic motive can not be what is at work in any case where the excluded companies are just wounded, and could not plausibly have been killed off. Most situations with aggrieved competitors are thus excluded, but one application was in the Microsoft case, where Microsoft could plausibly have hoped to completely destroy Netscape as a rival, even though ex post it turns out that Netscape would not even have been Microsoft's main competitor. It was because of the unusual facts of the Microsoft case that Robert Bork himself supported the government's case, comparing it to Lorain J ournal. See United States v. Microsoft, 253 F.3d 34 (D.C. Cir. 2001) (en banc) and Bork (1998).

Innes and Sexton (1994) and Segal and Whinston (2000) correct errors in Rasmusen, et al. (1989) and suggest other pricing schemes by which a firm can exploit even small economies of scale to make "naked exclusion" work. Suppose, for example, that a supplier offered exclusive contracts with a signing fee of $\$ 1$, but added an exculpatory clause: exclusivity would not bind, it explained, if fewer than $(90-13=) 77$ of the retailers signed. A retailer who signed would pocket the $\$ 1$ fee but face no binding constraint if other suppliers refused. As a result, "no retailer signing" would cease to be an equilibrium: all retailers would sign. ${ }^{8}$

These models suggest that courts should look skeptically at exclusive contracts that either (a) condition enforcement on the amount of competition or (b) include discriminatory terms. Such clauses potentially cause retailers to sign contracts even if they would otherwise prefer to avoid them. If the impact of such clauses is clear to the retailers, we can hope it will be clear to a judge too. ${ }^{9}$

Simpson and Wickelgren (2007) note that the effect of a "naked exclusion" strategy depends on whether an excluder sells to retailers or to final consumers. If he sells to competitive retailers, then he sells to firms that earn zero surplus in equilibrium anyway. They will pass along any added input cost to consumers and have little incentive to coordinate on the nobody-signs equilibrium. On the other hand, if the excluder sells to final consumers (or retailers who earn rents or quasi-rents, so their demand curves are downward sloping) then we must think what happens after breach, which the law allows so long as the breacher pays expection damages. If, as in the example above, the buyer does have downward-sloping demand and positive surplus, and is currently buying 15 units from the supplier at a price of $\$ 25$, it could breach, buy 30 units from an entrant at a price of $\$ 10$, pay damages equal to the supplier's pre-breach profit of $\$ 225$, and end up better off. It would be better off because it would pay $\$ 225$ less for the

8 Elhauge and Wickelgren (2012) thoughtfully discuss the effect that loyalty discounts might have on profitable exclusion.

9 For an experimental study of these tactics and others, see Landeo and Spier (2009). 
15 units it was buying before entry, but it also would earn surplus from buying 15 units more at the entrant's price of $\$ 10$. To be sure, the court would have to be economically wise in calculating expectation damages. Breach would be disastrous for the retailer if it ended up having to pay damages of $30 \times \$ 15$ because the court thought the retailer would have purchased 30 units from the original supplier at the original high price.

(2) Cartel Ringmaster. Sometimes, an upstream supplier with no market power can use exclusive-dealing contracts to coordinate a downstream retailer cartel. In effect, the supplier ensures that no retailer buys enough input to undercut other retailers. The supplier and retailers then split the monopoly rents among them, perhaps by pricing the input above marginal cost but below the monopoly level. Bork (p. 237) acknowledges this possibility in a discussion about a hypothetical case where an oil refiner acquires all U.S. gas stations: ${ }^{10}$

Foreclosure theory is like a conjuring trick: it causes you to look at the wrong level of the industry, in this case the refining level. The problem just stated is not vertical but horizontal; the evil is not foreclosure of rival refiners but the establishment of a retail monopoly.

Twenty years later, Judge Posner discussed a possible case of this in JTC Petroleum v. Piasa Motor Fuels, 190 F.3d 775 (7th Cir. 1999).

(3) Raising Rivals' Costs. Could exclusive-dealing contracts be profitable because they raise the costs of the supplier's rivals? The clearest form of "raising rivals' costs" turns on a move by one supplier to raise costs by driving up the price of an input its rivals use more intensively, an idea best known from Salop and Scheffman (1983) but with Williamson (1968) as a precursor. ${ }^{11}$ Suppose suppliers use a Leontief technology with a per-unit boron-to-zinc ratio of 1.8 to .2 for the excluder and 1 to 1 for its rivals. If market demand is inelastic and boron and zinc each start with a price of $\$ 1$, the product sells for $\$ 2$, which is $1.8^{*} \$ 1+$ $.2 * \$ 1$ for the excluder and $1 * \$ 1+1 * \$ 1$ for the others. If the excluder can raise zinc's price to $\$ 2$ by lobbying for a zinc tax, its own cost will rise only to $\$ 2.20$ (that is, $1.8^{*} \$ 1+.2^{*} \$ 2$ ), but its rivals' cost will rise to $\$ 3$ (that is, $1^{*} \$ 1+1 * \$ 2$ ). The excluder will price its products at $\$ 2.99$ and serve all customers. Cost-raising regulations are a common form of this. A classic example is Dupont's support for regulation to protect the ozone layer, not unrelated to its ownership of patents on the only products which would be legal after the regulation (see Smith [1998]).

It is one thing to raise costs using the government; it is another thing entirely to do it by cornering the market. Suppose the excluder tried to raise

10 The case is discussed in Scheffman and Higgins (2003). "Cartel ringmaster" is also one of the "raising rivals' costs" techniques in Krattenmaker and Salop (1986), discussed below.

11 This asymmetry is not stated outright in Salop and Scheffman (1983), but it is there in the form of their requirement that the excluder's average cost rise less than the residual demand curve he faces given the other firms' equilibrium sales. 
rivals' costs by driving up zinc prices through overbuying. The excluder will have to pay for useless zinc, of course. Moreover, the excluder cannot raise zinc prices by overbuying unless its new demand also replaces the old demand of its now-excluded rivals. If those rivals buy 50 units less, the excluder must buy and destroy (because reselling the zinc would drive the price back down) 50 units more - and at the new high price. Thus, the entire increase in the rivals' costs ends up being borne by the excluder.

Beyond the strategy of manipulating government policy to penalize rivals, the logic behind the claims about raising rivals' costs as a method of exclusion turns hazy. Krattenmaker and Salop (1986) do lay out two overbuying models ("bottleneck" and "real foreclosure"), but they ignore the question of whether the excluder could earn any profit through the strategy. Brennan (1988) argues that the "raising rivals' costs" literature either refers to horizontal practices already well-known (e.g. the cartel ringmaster), or simply uses new terminology to cloud analysis. Nonetheless, the literature remains enormously popular. As of J une 14, 2013, Krattenmaker and Salop (1986) had been cited 912 times, and Salop and Scheffman (1983) 1,134 times.

(4) Liquidated Damages: The Incumbent Can Profit from Entry. Suppose a monopoly incumbent and the existing customers see a new entrant looming who has much lower costs than the incumbent. Aghion and Bolton (1987) suggest that they could sign an exclusive-dealing contract with the precise intention of having it breached. The reason is that the contract would include a clause for substantial liquidated damages, what one might call "a disloyalty bonus". The customers would breach by buying from the new entrant at low prices, and pay damages to the incumbent. The entrant would charge low prices, because otherwise the customers would not buy from it, given the liquidated damages. In the end, the customers benefit from the low prices and the incumbent benefits from the damages. Only the entrant loses.

This is a rent-seeking use of an exclusive-dealing contract in which no exclusion actually occurs. This scheme does depend on liquidated damages being greater than actual damages for the incumbent, which courts in general do not enforce (see, e.g., Goetz and Scott [1977]). As a result, the idea is primarily of theoretical interest, except to show the danger of safe-harbor rules: clever people may figure out hitherto-unknown tricks to get round them. Antitrust might take a leaf from the Tax Code, which has "principal purpose" clauses to open up wiggle room for thwarting creative tax shelters (see U.S.C. Title 26 sections 269(a) and 357(b)(1)).

(5) Research \& Development. Chen and Sappington (2011) explore the effect of exclusive dealing contracts on research \& development. The effect of the contracts on R\&D, however, is almost certainly minor. Schumpeter (1950) argued that blatant merger-to-monopoly might increase R\&D levels. If even monopoly has an indeterminate effect on $R \& D$, we find it hard to believe that exclusive dealing contracts could have a substantial predictable effect. Even if they did, we 
do not know how one would determine the welfare implications of that effect-whatever it might be.

(6) Tying and Exclusive-Dealing. Whinston (1990) shows how tying can exclude competitors if there are the same sort of moderate economies of scale as in the divide-and-conquer literature (see also its description in Carlton [2001]). Suppose an island hotel requires its guests to eat at the hotel and only at the hotel, and not enough natives exist to support a separate fancy restaurant. The hotel can thereby charge the monopoly price to natives as well as to guests. Exclusive dealing is not the essence of this tactic, however; if the hotel merely told guests that if they ate at the hotel they could not eat anywhere else, they would choose to do all their eating outside the hotel and the tactic would fail. The essence is tying housing and dining.

People often view the "post Chicago" theoretical models as favoring government intervention more than the Chicago School framework, but that is not entirely true. We who come up with perverse game theory models are generally not doing it for ideological reasons, but more often out of curiosity and the joy of invention. Often these models are entirely impractical for use by judges, who are not experts, and often they are impractical for use even by experts, since key variables are unobservable except to executives inside the companies. "Often" is not "always", however. At a minimum, these models show that clever people can come up with ways to exclude their rivals unfairly, and at their best, they show how under very specific conditions courts should look carefully at excluding conduct.

\section{General Discussion.}

Basic economics dictates that courts treat exclusive contracts as legal per se, argued Bork. The price theory he used did indeed force that conclusion. Post-Bork, scholars have moved beyond basic price theory and found situations where exclusive contracts can generate inefficient results. Do these new models warrant a different legal rule? Bork wrote (p. 226):

There is a faint theoretical case, hardly worth mentioning, that vertical mergers can be used by very large firms for purposes of predation under exceptional circumstances, but it is highly doubtful that that narrow possibility has any application to reality.

Do the risks identified by the post-Bork models for exclusive contracts present more than a "faint theoretical case"?

Courts cost. Lawyers are not free, time lost to litigation is not free-and even after the time and effort invested, judges do not always "get it right." Scholars may model situations where exclusive-dealing contracts could generate bad results, but the models justify a rule other than Bork's per se legality only under limited circumstance: only if the benefits from the greater adjudicatory precision exceed the costs in lawyer fees, in time, and in the additional cases that 
judges (who now scrutinize all exclusive-dealing contracts more intensely) decide wrongly.

"The perfect is the enemy of the good," wrote Voltaire. Richard Epstein calls the principle "Blum's Law", after his late colleague Walter Blum: "In law, 95 percent is perfection." If judges cannot apply a theory with any accuracy, that theory should not be part of the law. In his 2008 article on Judge Bork's contribution to the law of exclusion, J udge Easterbrook said,

Judges are no better than the rest of us at predicting the future. My colleagues and I spend most of our time on cocaine prosecutions, employment discrimination, and the myriad other subjects within federal jurisdiction. We cannot hope to emulate students of industrial organization, and my friends who study that subject are themselves no great shakes at prediction.

If a theory requires taking too many cases past summary judgement to the stage of high-cost discovery, the law should ignore it.

"Exclusionary conduct has been the source of the most significant divide between Chicago School and post-Chicago commentators," wrote J onathan Baker in 2013. Yet even the most adamantly post-Chicago ("anti-Chicago" might be more accurate) scholars do not urge a return to the days before Bork. As Crane put it in his 2009 review of a book by several self-consciously "post-Chicago" scholars:

Not one of the [scholars] wants to pick up where we left off pre-Chicago. As Pitofsky acknowledges ..., "Virtually all ... share the view that U.S. antitrust enforcement, as a result of conservative economic analysis, is better today than it was during the Warren years."

Antitrust is a notoriously expensive field to litigate. Bork's per se rule that exclusive-dealing contracts are legal may bar a few meritorious claims, but it will benefit consumers if it protects firms from an avalanche of meritless but cost-raising claims. More recent developments warn that per se may be going too far, but scholars and judges seem now to agree on a strong presumption of legality. 


\section{References}

Aghion, Philippe and Patrick Bolton. 1987. "Contracts as a Barrier to Entry." The American Economic Review. 77: 388-401.

American Bar Association, Section of Antitrust Law, Sherman Act Section 2 Committee. 2006. "Resources for Exclusive Dealing Agreements: A New Frontier in Antitrust Litigation?" (March 29, 2006).

Bernheim, B. Douglas and Michael D. Whinston. 1998.“Exclusive Dealing.” The J ournal of Political Economy. 106: 64-103.

Bork, Robert H. 1954. "Vertical Integration and the Sherman Act: The Legal History of an Economic Misconception." The University of Chicago Law Review. 22: 157-201.

Bork, Robert H. 1978. The Antitrust Paradox: A Policy at War with Itself. New York: Basic Books.

Bork, Robert H. 1998. “What Antitrust Is All About.” The New York Times. (May 4, 1998).

Brennan, Timothy J. 1988. "Understanding Raising Rivals' Costs.” Antitrust Bulletin. 33: 95-114.

Bronsteen, Peter, Kenneth G. Elzinga, and David E. Mills. 2005. "Price Competition and Slotting Allowances.” Antitrust Bulletin. 50: 267- 284.

Carlton, Dennis W. 2001. “A General Analysis of Exclusionary Conduct and Refusal to Deal: Why Aspen and Kodak are Misguided." The Antitrust Law J ournal. 68: 659-xxx.

Chen, Yongmin and David E. M. Sappington. 2011. "Exclusive Contracts, Innovation, and Welfare." American Economic Journal: Microeconomics. 3: 194- 220.

Coase, Ronald H. 1979. "Payola in Radio and Television Broadcasting." J ournal of Law and Economics. 22: 269-328.

Crane, Daniel A. 2009. "Chicago, Post-Chicago, and Neo-Chicago: How the Chicago School Overshot the Mark: The Effect of Conservative Economic Analysis on U.S. Antitrust by Robert Pitofsky, Review by: Daniel A. Crane." The University of Chicago Law Review. 76: 1911-1934.

Easterbrook, Frank. 2008. "The Chicago School and Exclusionary Conduct." Harvard J ournal of Law and Public Policy. 31: 439-447. 
Elhauge, Einer \& Abraham L. Wickelgren. 2012. "Robust Exclusion through Loyalty Discounts with Buyer Commitment." xxxx

Farrell, J oseph. 2005. "Deconstructing Chicago on Exclusive Dealing." Antitrust Bulletin. 50: 465. xxx

Goetz, Charles J . and Robert E. Scott. 1977. “Liquidated Damages, Penalties and the Just Compensation Principle: Some Notes on an Enforcement Model and a Theory of Efficient Breach." Columbia Law Review. 77: 554-594.

Innes, R. and R. J. Sexton. 1994. "Strategic Retailers and Exclusionary Contracts." The American Economic Review. 84: 566-584.

J acobson, J onathan M. 2002. “Exclusive Dealing, 'Foreclosure,' and Consumer Harm." Antitrust Law J ournal. 70: 311-369.

Kaplow, Louis. 1985. "Extension of Monopoly Power Through Leverage." Columbia Law Review. 85: 515-556.

Klein, Benjamin. 2003. "Exclusive Dealing as Competition for Distribution on the Merits." George Mason Law Review. 12: 119-162.

Klein, Benjamin and Kevin M. Murphy. 2008. "Exclusive Dealing Intensifies Competition for Distribution." Antitrust Law J ournal. 75: 433-450.

Klein, Benjamin and Joshua D. Wright. 2007. "The Economics of Slotting Contracts." J ournal of Law and Economics. 50: 421-454.

Krattenmaker, Thomas G. and Steven C. Salop. 1986. "Anticompetitive Exclusion: Raising Rivals' Costs to Achieve Power over Price." Yale Law J ournal. 96: 209-293.

Landeo, Claudia M. \& Kathryn E. Spier. 2009. "Naked Exclusion: An Experimental Study of Contracts with Externalities." The American Economic Review. 99: 1850-1877.

Letwin, William L. 1953-1954. "The English Common Law Concerning Monopolies." The University of Chicago Law Review. 21:355--385 .

Lin, Y. Joseph. 1990. "The Dampening-of-Competition Effect of Exclusive Dealing." J ournal of Industrial Economics. 39: 209-223.

Marvel, Howard. 1982. "Exclusive Dealing." J ournal of Law and Economics. 25: 1-25. 
Meese, Alan J. 2005. "Exclusive Dealing and the Theory of the Firm." Antitrust Bulletin. 50: 371-439.

O’Brien, Daniel and Greg Shaffer. 1993. "On the Dampening-of-Competition Effect of Exclusive Dealing." J ournal of Industrial Economics. 42: 215-221.

Rasmusen, E.B., J. Mark Ramseyer and John Shepherd Wiley. 1991. "Naked Exclusion." The American Economic Review. 81: 1137-1145.

Salop, Steven C. and David T. Scheffman. 1983. "Raising Rivals' Costs." The American Economic Review. 73: 267-271.

Scheffman, David T. and Richard S. Higgins. 2003. "Twenty Years of Raising Rivals' Costs: History, Assessment, and Future." George Mason Law Review. 12: 371-387.

Schumpeter, Joseph A. 1950. Capitalism, Socialism and Democracy (3rd ed., New York: Harper).

Segal, Ilya R. and Michael D. Whinston. 2000. "Naked Exclusion: Comment." The American Economic Review. 90: 296-309.

Simpson, J ohn and Abraham L. Wickelgren. 2007. "Naked Exclusion, Efficient Breach, and Downstream Competition." The American Economic Review. 97: 1305-1320.

Smith, Brigitte. 1998. “Ethics of Du Pont's CFC Strategy 1975-1995." J ournal of Business Ethics. 17: 557-568.

Whinston, Michael D. 1990. "Tying, Foreclosure, and Exclusion.”

The American Economic Review. 80: 837-859.

Williamson, Oliver. 1968. "Wage Rates as a Barrier to Entry: The Pennington Case." The Quarterly J ournal of Economics. 85: 85-116.

Wright, J oshua D. 2006. "Antitrust Law and Competition for Distribution." Yale J ournal of Regulation. 23: 169-208. 